\title{
A meningitis carcinomatosa komplex megjelenése
}

\author{
Orbán-Szigeti Boglárka dr. ${ }^{1}$ - Papp Anikó dr. ${ }^{2}$ \\ Kamondi Anita dr. ${ }^{2}$ - Szekeres György Tibor dr. ${ }^{1}$ \\ ${ }^{1}$ Semmelweis Egyetem, Általános Orvostudományi Kar, Pszichiátriai és Pszichoterápiás Klinika, Budapest \\ ${ }^{2}$ Országos Klinikai Idegtudományi Intézet, Budapest
}

\begin{abstract}
Az emlőtumor miatt kezelt, majd gondozott beteget - több tünetmentes év után - fejfájás, szédülés, ataxia, megváltozott, furcsa viselkedés, emlékezetzavar és dezorientáció miatt neurológiai, majd belgyógyászati osztályokon vizsgálták. Az alapos kivizsgálás ellenére a tüneteit magyarázó organikus eltérést nem igazoltak, ugyanakkor már a kezdetektől felmerült a szomatizációs tünetképzés lehetősége, ezért pszichiátriai osztályos felvételére került sor. Az elvégzett vizsgálatok, illetve a klinikai kép regresszív állapotot valószínúsítettek. Terápiás próbálkozásaink ellenére a páciens állapota romlott, végül a megismételt neurológiai vizsgálatok meningitis carcinomatosát igazoltak. Az esettel szemléltetni kívánjuk, hogy a beteg premorbid múködési nívója, személyiségstruktúrája hogyan képes befolyásolni az ellátószemélyzetet, milyen külső és belső konfliktusokat válthat ki. A diagnózishoz vezető folyamat bemutatásával fel kívánjuk hívni a figyelmet az interdiszciplináris együttmúködés fontosságára.
\end{abstract}

Orv Hetil. 2021; 162(43): 1744-1748.

Kulcsszavak: emlőtumor, meningitis, konverzió, disszociatív zavar

\section{The complex presentation of carcinomatous meningitis}

Our patient with known breast cancer in her past medical history was hospitalized - after several asymptomatic years for headache, dizziness, ataxia, changed behaviour and disorientation. Thorough internal and neurologic investigations did not find any disease underlying her symptoms, therefore the possibility of somatization disorder was raised. Despite lege artis therapeutic interventions carried out on the psychiatry ward, the patient's condition deteriorated and repeated neurological examinations eventually revealed carcinomatous meningitis. With this case, we would like to illustrate how the patient's premorbid function level and personality features might influence the attitude and opinion of the health care personnel, and what kind of external and internal conflicts might be triggered. By presenting the complexity of the diagnostic work-up, we would like to emphasize the importance of interdisciplinary cooperation in the interest of our patients.

Keywords: breast cancer, meningitis, conversion, dissociative disorder

Orbán-Szigeti B, Papp A, Kamondi A, Szekeres GyT. [The complex presentation of carcinomatous meningitis]. Orv Hetil. 2021; 162(43): 1744-1748.

(Beérkezett: 2021. január 14.; elfogadva: 2021. március 30.)

\section{Rövidítések}

anti-TPO $=$ thyreoidea-peroxidáz elleni antitest; $\mathrm{CT}=(\mathrm{com}-$ puted tomography) komputertomográfia; CTA = (computed tomography angiography) komputertomográfiás angiográfia; EEG = elektroencefalográfia; FLAIR = (fluid-attenuated inversion recovery) folyadékcsillapító inverziós visszanyerése;
Her2 = a humán epidermalis növekedési faktor receptor 2-es típusa; $\mathrm{HR}+=$ hormonreceptor-pozitív; $\mathrm{MR}=$ (magnetic resonance) mágneses rezonancia; $\mathrm{PET}=$ pozitronemissziós tomográfia; SSRI = (selective serotonin reuptake inhibitors) szelektív szerotoninvisszavétel-gátlók 


\section{Esetbemutatás}

Az általunk választott eset komplexitását és fontosságát a betegség tüneteit létrehozó és alakító testi és lelki tényezők kölcsönhatása adja. Az 55 éves nő több társszakmát is érintő betegútja jól illusztrálja a komplex diagnosztikus intervenciók kihívásait és a döntéseket az objektív leleteken túlmenően befolyásoló szubjektív komponensek hatását, az együttmúködés fontosságát. A tumoros páciensek esetében a multidiszciplináris szemlélet kifejezett hangsúlyt kell, hogy kapjon, az onkopszichológia kiemelt szereppel bír e téren. Fontos az atípusos tünetek esetén a szomatikus háttér, a szervi okok alapos és megtervezett felderítése.

A távolabbi anamnézisnek a bemutatandó eset szempontjából releváns eseményei: 2008 októberében a bal oldali emlőbiopszia HR + carcinomát igazolt, novemberben mütétet végeztek (szövettani eredmény: pleiomorph invasive lobularis carcinoma, erôs hormonreceptor-expresszióval, Her2-negativitás mellett). 2009. januárban és februárban a beteg sugárkezelést kapott; 2009 októberében mindkét oldalon implantátum behelyezése történt, majd a páciens rendszeresen eljárt gondozásra. 2012 februárjában a jobb mellében csomót vett észre; májusban a mammográfiával és ultrahangvizsgálattal is igazolt elváltozás eltávolításra került, utólagos konzíliumok alapján nem az épben, így 2012 júniusában bőrmegtartó mastectomiát végeztek, az implantátum bennhagyásával. A mútét során az őrszemnyirokcsomó imprintcitológiával pozitív lett; a szövettan alapján több nyirokcsomóban is áttét igazolódott, mely helyenként a tokot is infiltrálta, az invazív lobularis carcinoma áttéteként. Tekintettel arra, hogy távoli áttét nem igazolódott, sugárkezelést alkalmaztak (48,6 Gy), amelyet a beteg jól tolerált. A 2018. márciusi hasi és kismedencei CT-, illetve a júniusi MR-vizsgálat kórosat nem igazolt. A szeptemberben elvégzett 'cancer' antigén 15-3 vizsgálat emelkedett szintet mutatott, míg a carcinoembrionalis antigén értéke a normáltartományban volt. A későbbiekben elvégzett ultrahangvizsgálat a pajzsmirigy jobb lebenyében szolid göböt írt le, az ekkor elvégzett laborvizsgálatok emelkedett anti-TPO-szintet mutattak.

Neurológiai osztályra első alkalommal 2018. november 17-én került felvételre a beteg bizonytalan természetû, elhúzódó zavartsággal járó rosszullétek miatt. A felvételt megelőző időszakban szédülés, fejfájás, ataxia, valamint bizonytalan eredetû rosszullétek miatt már több neurológiai rendelőben vizsgálták. A koponya-CTés CTA-vizsgálat kórosat nem mutatott. A rosszullétek hátterében epilepsziát gyanítottak; az etiológiakutatás kapcsán felmerült a virális encephalitis, illetve a tumoros anamnézisre tekintettel a meningealis terjedés, valamint az autoimmun vagy paraneoplasiás encephalitis lehetősége. A sürgősséggel elvégzett liquorvizsgálat (összfehérje, sejtek, liquorcukorszint) eltérést nem mutatott. Ennek ellenére a páciens antivirális és nagy dózisú szteroid-lökésterápiát kapott a virális, illetve a paraneoplasiás encephalitis továbbra is fennálló gyanúja miatt. A neurológiai osztályos kivizsgálás alatt elvégzett EEG-vizsgálatok kórosat nem igazoltak; a kontrasztanyagos koponyaMR-vizsgálat a tüneteket magyarázó intracerebralis eltérést nem jelzett, azonban a bal parietalis koponyacsonton egy kontrasztanyagot halmozó elváltozást igazolt. A liquorból készített üledék mikroszkópos vizsgálata néhány vér alakos elemet és kevés $(2 / 3 \mu \mathrm{l})$ fehérvérsejtet talált. A speciális limbicus encephalitis ellenes antitestek és onkoneuronális markerek vizsgálata negatív volt. A társuló, ismert magas anti-TPO-érték miatt a Hashimoto-encephalopathia lehetósége merült fel, emiatt a nagy dózisú szteroidterápia és a már megkezdett antivirális terápia folytatódott. Tumorkeresés keretében teljes test PET/CT vizsgálat történt, mely a thoracalis IV-es csigolya harántívén $1 \mathrm{~cm}$-es lyticus laesiót ábrázolt. A beteg obszervációja során észlelt viselkedéses tünetek számos, funkcionálisnak is értelmezhető elemet mutattak, emiatt felmerült a szomatizációs tünetképzés lehetősége is, így benzodiazepin- és SSRI-beállítás történt; ezeket a beteg az elbocsátását követően elhagyta. Az esettörténet ezen pontján egyelőre, többhetes obszervációt követően - kizárásos alapon - a Hashimoto-encephalopathia lehetôsége volt a legvalószínúbb [1]. A páciens emissziója után három nappal ismételten felvételre került fejfájás, látászavar, hányinger, hányás miatt, kollaptiform rosszullétet követően. A fizikális vizsgálat és a kontroll-koponya-CT új eltérést nem igazolt. A laboratóriumi leletek közül a kissé magasabb szérum-D-dimerszint emelhető ki, de sem a klinikum, sem a vérgázanalízis nem szólt thromboembolia mellett. A rosszullétek etiológiája továbbra sem volt meghatározható, a feltételezett Hashimoto-encephalopathia plauzibilis volt.

Az alapbetegségre, a koponya-MR-, valamint a PET/ CT vizsgálat eredményére tekintettel a beteg a javasolt onkológiai kontrollvizsgálaton megjelent, melynek során immunológiai és endokrinológiai konzíliumot terveztek. Az eredmények megérkezéséig, tekintettel a daganat statusára, az onkológiai terápiától eltekintettek.

A rosszullétek funkcionális komponensei miatt a beteg pszichológiai tanácsadáson is részt vett 2018. december 13-án. A találkozó során kifejezett vizelési ingerrel társult rosszulléte jelentkezett, kontaktusképtelen állapotba került. Paraméterei mindvégig stabilak voltak, új fokális neurológiai kórjelet nem észleltek. Hólyagkatéteren kb. $2000 \mathrm{ml}$ vizelet ürült. A sürgősséggel elvégzett EEGvizsgálat súlyos, döntően subcorticalis funkciózavart mutatott, emiatt még aznap ismételten felvételre került neurológiai osztályra. A megelőző rosszullétre amnéziás volt, fokális neurológiai kórjele továbbra sem volt. Az ismételt anti-TPO-szint-vizsgálat jelentős csökkenést mutatott, ugyanakkor a feltételezett Hashimoto-encephalopathiára való tekintettel plazmaferézis történt 5 alkalommal az orális szteroidterápia folytatása mellett. A feltételezett epilepsziás rosszullétek, valamint az EEG-n észlelt eltérések miatt antiepileptikum-terápia indult (levetiracetám). A kontroll-koponya-MR strukturális el- 
térést továbbra sem mutatott. Obszervációja alatt, az első plazmaferézis-kezelést követően, orthostasishoz társuló, balra irányuló, átmeneti, harmadfokú horizontorotátoros nystagmust észleltek, mely spontán megszűnt. A második plazmaferézist követően $1500 \mathrm{ml}$ vizelet retenciójához társuló, zavartsággal, dezorientációval járó rosszullét jelentkezett. A háttérben autoimmun agytörzsi múködészavart feltételeztek, a felszálló aktiváló rostok érintettségével, ami a korábbi hasonló rosszullétek alatti EEG-n észlelt diffúz meglassulást szintén magyarázhatta. A plazmaferézist követő kontroll-EEG-vizsgálat kórosat nem mutatott. Az utolsó plazmaferézist követően hasonló, nagyobb rosszullétet nem észleltek, de több alkalommal, pozícióváltásra fellépó átmeneti szédüléssel és balra irányuló II-III. fokú horizontorotátoros nystagmussal vagy jobb oldali hemifacialis spasmussal járó rosszullétek jelentek meg. Az otoneurológiai vizsgálat audiometriai eltérést nem igazolt, provokálható, balra irányuló nystagmust, valamint a jobb oldalon csökkent kalorikus reakciót jelzett; a kontrollvizsgálat kétoldali, bal túlsúlyú pontobulbaris érintettségre utaló eltérést mutatott. A rosszullétek kardiológiai okait kizárták. Az orthostasis hátterében így idegrendszeri megbetegedés, endokrin eredet, valamint a tartós fekvés oki szerepe merült fel. Az elvégzett vizsgálatok alapján továbbra is az agytörzsi érintettséggel járó Hashimoto-encephalopathia maradt az elsődleges diagnózis, amely azonban teljes mértékben nem magyarázta a tapasztalt tüneteket. Emiatt ismételten felmerült a funkcionális tünetképzés lehetősége. Disszociatív és konverziós mechanizmus kombinálódását feltételezték, emiatt pszichológus mielőbbi felkeresését, az SSRI-terápia folytatását javasolták.

Ezt követően halmozott otthoni rosszullétek miatt került a beteg ismételten visszavételre neurológiai osztályra. Felvételi vizsgálata során nystagmussal, zavartsággal, enuresissel társult rosszulléte volt, testén korábbi esések nyomai látszódtak. Az akut koponya-MR új keletû eltérést nem igazolt, a kontroll-liquorvizsgálat negatív volt. Bár video-EEG-monitorizálás során sem epileptiform aktivitás, sem egyéb múködészavar nem igazolódott, antiepileptikum-váltásra került sor. A pszichológiai vizsgálat felvetette a személyiségzavar, az organikus pszichoszindróma lehetőségét. Szteroid, antiepileptikum és SSRI kombinált kezelés mellett emittálták.

2019. február 20. és március 18. között, tervezett endokrinológiai kivizsgálás keretében, belgyógyászati osztályon vizsgálták. Aktív, szisztémás autoimmun betegségre utaló klinikai eltérést nem észleltek, metilprednizolonkezelés mellett és ennek szüneteltetése során is magasabb kortizolértékeket, illetve ezek diurnalis ritmusának felborulását észlelték, amelyet a feltételezett neuropszichiátriai betegség háttértünetének véleményeztek. Pajzsmirigymúködése euthyroid, az anti-TPO normális volt.

2019. március 18-án pszichiátriai osztályos átvétel történt, disszociatív zavar iránydiagnózissal. Osztályra érkezésekor a beteg a feltett kérdésekre kezdetben egyáltalán nem reagált, hosszas explorációs törekvést követő- en hosszú latenciaidővel, néhány szavas válaszokat adott. Felvételi pszichés statusát beszúkült tudat és a jelen egészségi állapota köré szerveződött gondolkodása jellemezte. Egyértelmú téveszme nem volt feltárható; pszichomotoriuma kifejezetten meglassult, a mimika és a pantomimika visszafogott volt. Érzelmileg gyengén kontrollált, esékeny hangulat jellemezte. Számos major stresszorra derült fény, melyek a tünetei kezdetével átfedést mutattak, így a funkcionális komponens gyanúját erősítették: másfél évvel korábban munkahelyváltás történt, és nyolc hónappal korábban ért véget a legutóbbi párkapcsolata. Hozzátartozója később elmondta, hogy bántalmazó kapcsolat volt, ám a páciens a megaláztatások ellenére sem tudott kellő időben kilépni a szituációból. Hospitalizációja során komplex pszichodiagnosztikai felmérést végeztünk. Ez infantilis érzelmi életet írt le erős hangulatvezéreltséggel, elfojtásos elhárításokkal, teátrális öndemonstrálással, konverziós-szomatizációs tendenciával, érzelmi megterhelés hatására a mentális szabályozás színvonalának jelentős zuhanásával, fokozott regressziós készséggel, feszültség hatására könnyen kialakuló gondolati és értelmi beszúkültséggel. Összességében hiszteroid karakterszerkezet talaján kialakult regresszív állapot volt a kórisme.

Mindezek mellett azonban a pszichiátriai osztályon is több alkalommal fordultak elő figyelmeztető jel nélkül, hirtelen kialakuló rosszullétek, melyek kb. 30 másodpercig tartottak, kontaktusképtelenség, tónustalanság kíséretében. A „rohamokra” amnéziás volt. A rosszullétek kezdetben egyértelműen funkcionális komponenseket is mutattak, mint az aktív szemhéjzárás vagy a megjelenésük „időzítése”. Az egyébként természetes jelenség, hogy érzelmileg hangsúlyos témák érintésekor vegetatívszomatikus jelek is kísérik a kommunikációt. A beteg esetében azonban a fent leírt, komplex „rosszullétek” formájukban jelentősen meghaladták ezek szokványos mértékét és minőségét is.

A diagnosztikai kihívás során, ahogyan a páciens ellátása során mindvégig, a vélemények ütközése az orvoscsoportokon, az ellátószemélyzeten belül is pszichodinamikai folyamatokat indított el, feszültségeket generálva polarizálva az ellátóteameket az empátia, az együttérzés, illetve az objektív szakmai eljárás erővonalai mentén.

Tekintettel az esékeny hangulatra, melyet a szorongás jelentős mértékben aggravált, fluoxetin gyógyszeres kezelést kezdtünk, amelyet a beszúkült, testi panaszok köré szerveződő gondolkodás miatt kis dózisú amiszulpriddal kombináltunk. A kezelés előrehaladtával a beteg állapota javult: a „rohamok” gyakorisága és hossza csökkent, a „funkcionális” komponensek eltüntek. A kezelésbe bevont gyógytornász is beszámolt arról, hogy a páciens sokkal aktívabb, kommunikatívabb, és igyekszik a feladatokat végrehajtani. A javulás részben a pszichofarmakonok, részben a pszichoterápiás megközelítés eredményének volt tulajdonítható. Az élettörténeti adatok, a pszichodiagnosztika és a megfigyelt viselkedés alapján egyértelmú volt, hogy a pszichodinamikai tényezők je- 
lentős szerepet játszottak állapotában. A pszichés állapot relatív javulása ellenére azonban hamarosan progresszió következett, ami az organikus etiológia determináló szerepét erősítette: kooperációja jelentősen romlott, a „rohamok" hossza ismét nőtt, a megjelenési forma is változott - a beteg a teljes testében tónustalanná vált, bizarr végtagrángások, jobb oldali perifériás facialis paresis jelentkezett. A rosszullét alatt elvégzett EEG-vizsgálat diffúz encephalopathiára utalt, és jobb frontálisan epileptiform eltéréseket mutatott [2].

2019. április 12-én a páciens ismételten felvételre került neurológiai osztályra, ahol jobb oldali perifériás facialis paresis és bal felső végtagi jelzett gyengeség volt észlelhető, emellett epizodikusan jelentkező kontaktusképtelen állapottal, jobbra irányuló horizontális nystagmussal, bal oldali végtaggyengeséggel, illetve klonizációval járó rosszullétek jelentkeztek, melyek egy óra elteltével spontán megszűntek. A kontroll-EEG-n kifejezett diffúz meglassultság mellett epileptiform jeleket nem észleltek. $\mathrm{Az}$ újabb natív koponya-CT-, majd a kontrasztanyagos MR-vizsgálat jelentősen tágult supraventricularis kamrarendszert ábrázolt, a kamraszarvak körüli liquorimbibitióra utaló eltérésekkel. A kontrasztanyagos felvételeken a döntően frontálisan és occipitalisan észlelt FLAIR-jelfokozódás leptomeningealis folyamat jelenlétére utalt. A páciens kivizsgálása során ezt megelőzően egy alkalommal, 2018 novemberében készült kontrasztanyagos MR-vizsgálattal összevetve azonban lényegi eltérés nem ábrázolódott. A kamratágulat miatt terápiás liquorlebocsátás történt, melynek során a liquor igen nagy nyomással ürült. Többszöri punkciót követően a beteg állapota rohamosan javult. A lebocsátott liquor rutinvizsgálata során a sejtszám kissé emelkedett volt (10-22/3 ㅆ), és az ülepítés során kórosnak imponáló sejteket azonosítottak. A neuropatológus a liquor citológiai vizsgálata során malignitásra utaló sejteket írt le. A részletes immunhisztokémiai feldolgozás alapján a liquorban talált tumorsejtek a korábbi emlőcarcinoma leptomeningealis áttétének feleltek meg. A lelet megmagyarázta az időben fokozatosan progrediáló neurológiai-pszichiátriai tüneteket [3].

A kórkép azonosítása után a korábban végzett teljes test PET/CT, valamint a koponya-MR-vizsgálatok képanyagát ismételten áttekintettük, különös tekintettel arra, hogy a meningealis carcinomatosis az első diagnosztikai gondolatok egyike volt, de strukturális eltérést az ismételt alapos elemzés sem igazolt.

A diagnózis ismeretében a beteg onkológiai gondozásba került.

\section{Megbeszélés}

A bemutatott eset komplexitását a betegség tüneteit létrehozó és alakító testi és lelki tényezők bonyolult kölcsönhatása adja. A pszichés oldalt a személyiségténye- zók, élethelyzetek, a betegségre, illetve a párkapcsolati nehézségekre adott, funkcionális testi panaszok köntösébe bújt pszichés válaszreakciók képviselik, míg a testi oldalt a meningitis carcinomatosa lassú progressziója során jelentkező atipikus és folyamatosan változó szomatikus tünetek.

Fontos kiemelni, hogy Mehnert és mtsai 2014. évi közleménye alapján a rákos betegek 32\%-ánál legalább egy mentális betegséget diagnosztizálnak. Az emlőcarcinoma esetén a legmagasabb (42\%) a valószínúsége annak, hogy a diagnózist követő 4 héten belül valamilyen mentális betegség jelentkezzen. Szorongásos zavar 16,81\%-ban, míg disszociatív-konverziós zavar 8,55\%ban jelenik meg [4]. Annak ellenére, hogy a kivizsgálás state-of-the-art módszerekkel történt, és a meningitis carcinomatosa már a legelső neurológiai felvétel alkalmával felmerült, a kórismét csak hónapokkal később, a betegség jelentős progressziója után lehetett felállítani. A 2018 novemberében leírt, csontmetasztázisnak imponáló eltérések az onkológiai szakvélemény alapján nem voltak elégségesek az onkológiai terápia folytatására. A változékony tüneti kép és a lépésről lépésre feltárt organikus háttér közötti kauzális kapcsolat feltételezése nem volt a beteg ellátásában részt vevő egészségügyi teamek számára mindenkor meggyőző, a kételyek idején jellemzően a „hisztériás”, funkcionális etiológia került előtérbe magyarázatként.

Ahogyan azt korábban említettük, a páciens ellátása során a vélemények nemegyszer ütköztek. Az attitűdök egyike a mély empátia, a szenvedővel való intenzív együttérzés felől indul, és mobilizál kitartó és olykor a racionális döntéseken túlmutató erőfeszítéseket a diagnosztikus és terápiás mezőben egyaránt. A másik vonulat a hứvös, professzionális, elfogulatlan szakmai attitűd. Esetünk mind a bonyolultsága, mind a betegnek és családjának okozott hatalmas szenvedés révén mindkét típusú viszonyulást aktiválta, és az idő előrehaladtával polarizálta is, feszültséget váltva ki. A saját mentálhigiénénk érdekében ezeket a - ha enyhébb mértékben is, de rendszeresen előforduló - feszültségeket tudatosítani célszerü, és így a destruktív konzekvenciák helyett, a betegek érdekét szolgálva tud épülni a közösség.

\section{Következtetés}

Esetünk felhívja a figyelmet a meningitis carcinomatosa organikus pszichoszindrómát kiváltó hatására, amely megjelenhet minimális neurológiai tünetek mellett is, és rávilágít az organikus eredet fontosságára. A bemutatott eset bizonyítja, hogy a különböző szakterületeknek - pszichiátria, neurológia, onkológia, endokrinológia, patológia - szoros integrációban kell együttmúködniük, hogy az összetett diagnosztikai munkát igénylő esetekben a helyes diagnózis idejében megszülessen. 
Anyagi támogatás: A közlemény megírása anyagi támogatásban nem részesült.

Szerzôi munkamegosztás: A kézirat elkészítésében a szerzők közösen vettek részt. A cikk végleges változatát valamennyi szerző elolvasta és jóváhagyta.

Érdekeltségek: A szerzőknek nincsenek érdekeltségeik.

\section{Irodalom}

[1] Menon V, Subramanian K, Thamizh JS, et al. Psychiatric presentations heralding Hashimoto's encephalopathy: a systematic review and analysis of cases reported in literature. J Neurosci Rural Pract. 2017; 8: 261-267.
[2] Ellul P, Gasnier M, Trebossen V, et al. Immune activation and deficit in neurotransmitters synthesis in treatment resistant depression: about a case of Hashimoto encephalopathy. Clin Psychopharmacol Neurosci. 2020; 18: 463-466.

[3] Damaske M, Panarese V, Casey S, et al. Leptomeningeal carcinomatosis secondary to adenocarcinoma of the breast: a cadaveric case report. Cureus 2021; 13: e12693.

[4] Mehnert A, Brähler E, Faller H, et al. Four-week prevalence of mental disorders in patients with cancer across major tumor entities. J Clin Oncol. 2014; 32: 3540-3546.

(Orbán-Szigeti Boglárka dr., Budapest, Ráth György u. 4/3/5., 1123 e-mail: orbanbogi@yahoo.com)

\section{"Discordia fit carior concordia." (Széthúzásnál kedvesebb az egyetértés.)}

A cikk a Creative Commons Attribution 4.0 International License (https://creativecommons.org/licenses/by/4.0/) feltételei szerint publikált Open Access közlemény, melynek szellemében a cikk bármilyen médiumban szabadon felhasználható, megosztható és újraközölhetö, feltéve, hogy az eredeti szerzỏ és a közlés helye, illetve a CC License linkje és az esetlegesen végrehajtott módositások feltüntetésre kerülnek. (SID_1) 